\title{
PENERAPAN LAYANAN BIMBINGAN KELOMPOK MELALUI TEKNIK PERMAINAN SIMULASI DAN UNTUK MENINGKATKAN KECERDASAN EMOSI SISWA
}

\author{
${ }^{1)}$ Dewi Melianasari \\ ${ }^{1}$ SMA Negeri 24 Bandung \\ Email: cimotarifian@gmail.com
}

\begin{abstract}
From the results of a needs assessment Sims Exel and observations made by researchers, that the students of class XI MIA five emotional intelligence is still moderate. It can be seen from the overflow of student expression while classmate or when PBM progress. Action Research Guidance and Counseling originated from the problems contained in class XI MIA 5 that emotional intelligence are in the moderate category. This study aims to improve emotional intelligence class XI MIA 5 SMA Negeri 24 Bandung through the implementation of Guidance Services Group. The results obtained in this study a value of instruments that reveal the emotional intelligence of students. The results obtained in the first cycle of a $66.77 \%$ increase to $66.80 \%$. In the second cycle with the result of $66.80 \%$ increase to $71.99 \%$. Bahwasannya all activities in this research from planning, implementation, observation and reflection greatly affect the success of the action. This is indicated by an increase in the application of emotional intelligence and group counseling services through engineering simulation game MIA 5 Class XI SMAN 24 Bandung.
\end{abstract}

Keywords: Guidance Services Group, Simulation Games .

\section{A. PEndahuluan}

Manusia adalah makhluk sosial, secara kodrati dia selalu hidup dan bekerjasama dengan orang lain. Hampir tidak ada suatu produk budaya yang dibuat sendiri, dan tidak ada kemajuan yang dicapai manusia tanpa bantuan atau kerjasama dengan orang lain. Manusia selalu saling tergantung dan membutuhkan. Keterputusan hubungan dengan orang lain dapat menimbulkan kesepian, kesedihan, bahkan kesulitan (Suherman:2011).

Siswa pada jenjang Sekolah Menengah Atas merupakan individu dalam fase remaja. Fase ini merupakan fase yang sangat penting yang diawali dengan matangnya organ-organ fisik (seksual) sehingga mampu bereproduksi. Menurut Yusuf (2012:97) Pada usia remaja awal, perkembangan emosinya menunjukkan sifat yang sensitif dan reaktif yang sangat kuat terhadap berbagai peristiwa atau situasi sosial, emosinya bersifat negatif dan temperamental (mudah tersinggung/marah, atau mudah sedih/murung).

Sifat sensitif dan reaktif yang sangat kuat, dapat kita ketahui dalam hubungan dengan teman sebaya. Remaja lebih sering adu argumen dalam rangka mempertahankan pendiriannya. Sebagai contoh, kecewa ketika hasil kerja kelompok nilainya lebih rendah daripada kelompok lain. Maka mereka akan menunjukkan rasa kecewa dan terkadang tidak mau lagi untuk kerja kelompok dengan komposisi anggota yang sama serta saling menyalahkan satu sama lain. Karena, masa ini merupakan puncak emosionalitas, yaitu perkembangan emosi yang tinggi.

Perkembangan emosi yang tinggi yang ditunjukkan dengan sikap kecewa, 
marah, benci dan seterusnya apabila hanya dibiarkan begitu saja akan mempengaruhi kesehatan kepribadian remaja. Terutama siswa menjadi kurang mampu dalam mengolah kecerdasan emosinya. Oleh karena itu dibutuhkan adanya partisipasi baik dari keluarga, masyarakat, dan lingkungan pendidikan.

Kurikulum 2013 memberikan kesempatan kepada siswa untuk berperan aktif dalam kegiatan pembelajaran yang dikategorikan dalam tiga aspek penilaian yaitu Kognitif, Afektif dan Psikomotorik. Tujuan guru pembimbing atau konselor sekolah dalam rangka meningkatkan keceredasan emosi siswa sesuai dengan aspek afektif. Aspek afektif mencakup watak perilaku seperti perasaan, minat, sikap, emosi dan nilai.

Pendidikan merupakan salah satu unsur yang dapat mewujudkan manusia menjadi lebih mandiri, memiliki kualitas Sumber Daya Manusia, berkepribadian sehat dan bermoral kuat. Dalam rangka mewujudkan siswa menjadi individu yang berkepribadian sehat dan moral kuat dalam hal ini meningkatkan kecerdasan emosi, diperlukan peran aktif guru pembimbing atau konselor sekolah.

Kecerdasan emosi merupakan kapasitas manusiawi yang dimiliki seseorang dan sangat berguna untuk menghadapi, memperkuat diri, atau mengubah kondisi kehidupan yang tidak menyenangkan menjadi suatu hal yang wajar untuk diatasi (Haryanto:2011)

Menurut

(Goleman

dalam

Haryanto:2011) biasanya pada orang-orang yang murni hanya memiliki kecerdasan akademis tinggi, mereka cenderung memiliki rasa gelisah yang tidak beralasan, terlalu kritis, rewel, cenderung menarik diri, terkesan dingin dan cenderung sulit mengekspresikan kekesalan dan kemarahannya secara tepat.
Agar individu dapat mengelola dan meningkatkan kecerdasan emosinya, maka diperlukan adanya bimbingan yang diberikan oleh guru pembimbing atau konselor melalui layanan bimbingan dan konseling.

Bimbingan dan konseling sebagai salah satu komponen sekolah yang memegang peranan penting dalam upaya perkembangan siswa terutama dalam sikap afektifnya. Karena dengan belajar, siswa mampu memahami segala kelebihan dan kekurangannya.

Bimbingan pada hakikatnya bertujuan memberikan bantuan kepada seluruh siswa agar mereka tercapai dalam hal penyesuaian diri, perkembangan yang optimal, serta menjadi individu yang lebih mandiri.

Layanan bimbingan dan konseling yang tepat dalam meningkatkan kecerdasan emosi siswa adalah dengan menerapkan layanan bimbingan kelompok melalui teknik simulasi permainan. Kegiatan ini akan mengungkap pengaruh pemberian layanan tersebut terhadap peningkatan kecerdasan emosi siswa. Seperti penelitian yang pernah dilakukan oleh Fuadah (2012) "metode permainan simulasi dapat mengembangkan kecerdasan emosional siswa sekolah dasar." Goleman (Fajrin, 2012:24) memperluas kesadaran emosional menjadi lima wilayah utama, yaitu mengenali emosi diri, mengelola emosi, memotivasi diri sendiri, mengenali emosi orang lain dan membina hubungan.

Rumusan masalah penelitian dijabarkan dalam pertanyaan secara umum "Apakah kecerdasan emosi siswa dapat meningkat melalui layanan bimbingan kelompok dengan teknik permainan simulasi pada siswa kelas XI MIA 5 SMA Negeri 24 Bandung Semester 4 Tahun Pelajaran 2015-2016?. Secara khusus; (a) 
Bagaimana prosedur penerapan layanan bimbingan kelompok dengan teknik permainan simulasi dalam meningkatkan kecerdasan emosi siswa kelas XI MIA 5 SMA Negeri 24 Bandung Semester 4 tahun pelajaran 2015-2016?; (b) Apakah dengan teknik permainan simulasi dapat meningkatkan kecerdasan emosi?. Tujuan umum penelitian ini yaitu untuk mendeskripsikan peningkatan kecerdasan emosi siswa melalui layanan bimbingan kelompok dengan teknik permainan simulasi pada siswa kelas XI MIA 5 SMA Negeri 24 Bandung tahun pelajaran 2015-2016. Secara khusus; (a) Untuk menganalisis prosedur yang digunakan dalam meningkatkan kecerdasan emosi siswa melalui layanan bimbingan kelompok dengan teknik permainan simulasi; (b) Untuk mendapatkan informasi empirik tentang dampak meningkatnya kecerdasan emosi siswa melalui layanan bimbingan kelompok dengan teknik permainan simulasi.

\section{B. KAJIAN LITERATUR \\ 1. Kecerdasan Emosi}

Kecerdasan emosi merupakan kapasitas manusiawi yang dimiliki oleh seseorang dan sangat berguna untuk menghadapi, memperkuat diri, atau mengubah kondisi kehidupan yang tidak menyenangkan menjadi suatu hal yang wajar untuk diatasi. Goleman (2005:512) mendefinisikan kecerdasan emosi sebagai berikut:

"Kecerdasan emosi atau emotional intelligence merujuk kepada kemampuan mengenali perasaan diri kita sendiri dan perasaan orang lain, kemampuan memotivasi diri sendiri, dan kemampuan mengelola emosi dengan baik pada diri sendiri dan dalam hubungan dengan orang lain."

Salovey dan Mayer (Goleman,
2005:513) mendefinisikan kecerdasan emosi sebagai "kemampuan memantau dan mengendalikan perasaan sendiri dan orang lain serta menggunakan perasaan-perasaan itu untuk memandu pikiran dan tindakan." Sedangkan Salovey dan Mayer (Cliffe, 2011:206) juga menggambarkan kecerdasan emosi sebagai:

"Jenis kecerdasan sosial yang melibatkan kemampuan untuk memantau emosi diri sendiri dan orang lain, untuk membedakan emosi keduanya, dan menggunakan informasi tersebut untuk membimbing fikiran dan tindakan seseorang."

Goleman (Fajrin, 2012:22) menyebutkan lima dasar kecakapan emosi dan sosial dalam kecerdasan emosi yaitu sebagai berikut:

a. Kesadaran diri: Mengetahui apa yang kita rasakan pada suatu saat, dan menggunakannya untuk memandu pengambilan keputusan untuk dirinya sendiri, memiliki tolok ukur yang realistis atas kemampuan diri dan kepercayaan diri yang kuat.

b. Pengaturan diri: Menangani emosi kita sedemikian sehingga berdampak positif kepada pelaksanaan tugas, peka terhadap kata hati dan sanggup menunda kenikmatan sebelum tercapainya suatu sasaran, mampu pulih kembali dari tekanan emosi.

c. Motivasi: Menggunakan hasrat kita yang paling dalam untuk menggerakkan dan menuntun kita menuju sasaran, membantu kita mengambil inisiatif dan bertindak sangat efektif, dan untuk bertahan menghadapi kegagalan dan frustasi.

d. Empati: Merasakan apa yang dirasakan orang lain, mampu memahami perspektif mereka, menumbuhkan 
hubungan saling percaya dan menyelaraskan diri dengan bermacam-macam orang.

e. Keterampilan Sosial: Menangani emosi kita dengan baik ketika berhubungan dengan orang lain dan dengan cermat membaca situasi dan jaringan sosial, berinteraksi dengan lancar, menggunakan keterampilan-keterampilan ini untuk mempengaruhi dan memimpin, bermusyawarah dan menyelesaikan perselisihan dan untuk bekerjasama dan bekerja dalam tim.

\section{Layanan Bimbingan Kelompok}

Nurihsan (Lesmana, 2012:17) bimbingan kelompok merupakan bantuan terhadap individu yang dilaksanakan dalam situasi kelompok. Bimbingan kelompok dapat berupa penyampaian informasi ataupun aktivitas kelompok yang membahas masalah-masalah pendidikan, pekerjaan, pribadi dan sosial.

Sedangkan Rusmana (2009:13) dalam pelaksanaannya, kegiatan bimbingan dapat dilakukan secara individual maupun kelompok. Dalam situasi tertentu dimana suatu masalah tidak dapat ditangani secara individual, situasi kelompok dapat dimanfaatkan untuk menyelenggarakan layanan bimbingan bagi siswa. Yang menjadi sasaran dalam bimbingan kelompok pada hakikatnya sama dengan sasaran dalam bimbingan pada umumnya yakni individu. Individu yang dimaksud disini bisa berupa individu sebagai bagian dari kelompok, atau semua individu yang tergabung dalam kelompok. Bimbingan kelompok menggunakan situasi kelompok sebagai media untuk memberikan layanan bantuan kepada individu. Berdasarkan pemaparan di atas, maka bimbingan kelompok dapat didefinisikan sebagai suatu proses pemberian bantuan kepada individu melalui suasana kelompok yang memungkinkan setiap anggota untuk belajar berpartisipasi aktif dan berbagi pengalaman dalam upaya pengembangan wawasan, sikap dan atau keterampilan yang diperlukan dalam upaya mencegah timbulnya masalah atau dalam upaya pengembangan pribadi.

Prayitno (Lesmana, 2012:18) menyatakan bahwa tujuan bimbingan kelompok adalah sebagai berikut:

a. Tujuan Umum

Tujuan umum kegiatan bimbingan kelompok adalah berkembangnya kemampuan sosialisasi siswa, khususnya kemampuan komunikasi peserta layanan. Dalam kaitan ini, sering menjadi kenyataan bahwa kemampuan bersosialisasi/berkomunikasi seseorang sering terganggu perasaan, pikiran, persepsi, wawasan dan sikap tidak objektif, sempit dan terkungkung serta tidak efektif.

b. Tujuan Khusus

Secara khusus, bimbingan kelompok bertujuan untuk membahas topik-topik tertentu yang mengandung permasalahan aktual dan menjadi perhatian peserta. Melalui dinamika kelompok yang intensif, pembahasan topik-topik itu mendorong pengembangan perasaan, pikiran, persepsi, wawasan, sikap yang menunjang diwujudkannya tingkah laku yang lebih efektif. Dalam hal ini kemampuan berkomunikasi verbal maupun non verbal juga ditingkatkan.

\section{METODE PENELITIAN}

Pendekatan yang digunakan dalam penelitian ini adalah dengan melakukan pendekatan kuantitatif. Penelitian dengan menggunakan pendekatan kuatitatif adalah suatu pendekatan yang memungkinkan dilakukannya pencatatan dan analisis data hasil penelitian secara eksak dengan menggunakan perhitungan-perhitungan statistik mengenai tingkat efektivitas 
bimbingan kelompok melalui teknik permainan simulasi untuk meningkatkan kecerdasan emosi siswa secara nyata dalam bentuk angka sehingga memudahkan proses analisis dan penafsirannya.

Metode yang digunakan dalam penelitian adalah metode penelitian tindakan (action research). Penelitian tindakan dipilih atas dasar pertimbangan dalam mencari solusi dari permasalahan siswa bagaimana caranya untuk meningkatkan kecerdasan emosi dengan menggunakan teknik permainan simulasi. Karena di dalam penelitian tindakan terdapat proses evaluasi dan perbaikan setiap siklus. Penelitian tindakan bertujuan untuk menggambarkan proses tindakan yang berupa layanan bimbingan kelompok dengan menggunakan teknik permainan simulasi untuk meningkatkan kecerdasan emosi siswa.

Populasi yang digunakan dalam penelitian ini adalah kelas XI MIA 5 SMAN 24 Bandung semester 4 tahun pelajaran 2015-2016. Pertimbangan dalam menentukan populasi ini adalah:

a. Siswa kelas XI MIA 5 SMAN 24 Bandung adalah invidu yang berada pada usia remaja awal yang mengalami transisi secara fisik dan psikologis.

b. Siswa kelas XI MIA 5 SMAN 24 Bandung memiliki tuntutan akademik yang tinggi, kompetitif dan disiplin yang tinggi. Prestasi tinggi yang diperoleh siswa akan lebih berkualitas apabila diimbangi dengan kecerdasan emosi yang tinggi.

c. SMAN 24 Bandung merupakan salah satu sekolah unggulan di wilayah Bandung Timur yang menerima siswa dari status sosial, ekonomi dan budaya yang heterogen sehingga memiliki aneka ragam masalah baik masalah pribadi, sosial, belajar maupun karir yang dihadapi oleh siswa yang salah satu permasalahan yang berkaitan dalam bidang tersebut adalah kecerdasan emosi.

Sampel penelitian ditentukan dengan menggunakan teknik purposive sampling yaitu teknik pengambilan sampel yang didasarkan tujuan tertentu, Lesmana (2012:34).

Pemilihan sampel berdasarkan:

a. Data kebutuhan siswa yang terdapat dalam lembar jawaban Sims Exel kelas XI MIA 5 menunjukkan hampir $70 \%$ siswa membutuhkan peningkatan dalam kecerdasan emosi.

b. Aktivitas yang dilakukan siswa selama di sekolah baik dalam aktivitas PBM maupun ketika istirahat menunjukkan masih lemahnya kecerdasan emosi siswa dalam mengenali emosi sendiri untuk membina hubungan yang baik dengan teman sebaya.

Data yang dibutuhkan dalam penelitian yaitu tentang kecerdasan emosi siswa kelas XI MIA 5 SMA Negeri 24 Bandung. Angket yang digunakan merupakan angket terstruktur dengan bentuk jawaban tertutup. Siswa sebagai responden hanya perlu menjawab pernyataan dengan cara memilih alternatif jawaban yang telah disediakan.

1. Pengolahan Data

Penelitian tindakan ini bertujuan untuk mengetahui kecerdasan emosi siswa dengan menggunakan teknik permainan simulasi bagi kelas XI MIA 5 SMA Negeri 24 Bandung Semester 4 tahun pelajaran 2015-2016. Peningkatan 
kecerdasan emosi siswa dapat diketahui berdasarkan angket yang diberikan selama konselor memberikan tindakan pada siklus pertama dan kedua. Angket tersebut diberikan sebanyak tiga kali yaitu pre test pada siklus pertama, post test pada siklus pertama sekaligus sebagai pre test siklus kedua, dan post test pada siklus kedua.

2. Hasil

Hasil yang diperoleh dalam penelitian ini berupa nilai instrumen yang mengungkap kecerdasan emosi siswa. Hasil yang diperoleh pada siklus I dari $66,77 \%$ meningkat menjadi $66,80 \%$. Pada siklus II dengan hasil $66,80 \%$ meningkat menjadi $71,99 \%$.

\section{HASIL DAN PEMBAHASAN}

Peningkatan nilai pre tes dan pos tes dari siklus I ke siklus II tersebut dibuktikan dengan:

a. Siswa lebih bisa mengenali emosinya sendiri sehingga mereka lebih mudah untuk mengelola emosi yang mereka alami.

b. Siswa sudah mampu mengelola emosinya, yang dapat dilihat dari berbagai ekspresi wajah yang ia tunjukkan ketika tidak bisa memiliki posisi yang sama dengan sesama anggota kelompok (tidak cemas).

c. Siswa dalam kesatuan kelompok menunjukkan sikap yang optimis dalam menyelesaikan permainan simulasi yang ia laksanakan.

d. Siswa dapat menerima pesan dari teman sekelompoknya dengan menggunakan isyarat tertentu sehingga dapat menyelesaikan tugasnya tersebut.

e. Siswa aktif dalam mencari alternatif agar berhasil dalam permainan Benang Kusut sehingga dalam satu kelompok bisa saling berhadapan.

\section{E. SIMPULAN DAN REKOMENDASI}

Dari pemaparan di atas, dapat disimpulkan bahwa, penerapan layanan bimbingan kelompok melalui teknik permainan simulasi efektif dalam meningkatkan kecerdasan emosi siswa. Dari hasil penelitian ini, sebagaimana yang telah dilakukan oleh peneliti bahwa perkembangan siswa secara emosi yang ditunjukkan dari mimic wajah yang terlihat oleh guru maka dapat dimanfaatkan untuk melakukan proses komunikasi kepada siswa yang bersangkutan agar maksud dan tujuan serta tugas-tugas belajar dapat berjalan dengan interaktif.

\section{F. REFERENSI}

Effendi, Agus. 2005. Revolusi Kecerdasan Abad 21. Bandung: Alfabeta.

Fuadah, Refi Tsamaratul. 2012. Penggunaan Metode Permainan Simulasi untuk

Mengembangkan Kecerdasan Emosional Siswa SD Kelas Atas. Skripsi. Jurusan PPB UPI Bandung. Tidak Diterbitkan.

Goleman, D (a.b. T. Hermaya). 2005.

Kecerdasan Emosi untuk

Mencapai Puncak

Prestasi. Jakarta: Gramedia

Pustaka.

Helma. 2001. Pengembangan Alat Ukur Kecerdasan Emosi Siswa Sekolah 
Menengah. Tesis. Prodi BP PPS

UPI Bandung. Tidak Diterbitkan.

Kemendikbud. 2013. Pedoman

Peminatan Peserta Didik. Jakarta:

BPSDMP dan

PMP.

Lesmana, Asep Rohiman. 2012.

Efektifitas bimbingan Kelompok melalui Teknik

Bercerita untuk Mengembangkan Karakter Siswa. Skripsi. Prodi PPB FIP UPI. Tidak Diterbitkan.

Ramli, M. 2007. Model Konseling melalui Permainan Simulasi untuk Meningkatkan Kecerdasan Emosional Siswa Sekolah Menengah Pertama. Disertasi. UPI Bandung. Tidak Diterbitkan.

Rusmana, Nandang. 2009. Bimbingan dan Konseling Kelompok di Sekolah:

Metode, Teknik dan Aplikasi. Bandung: Rizqi Press.

Salovey, P., \& Mayer, J. D. 1990.
Emotional Intelligence. [Online]. Tersedia:

http://www.unh.edu/emotional.intelligenc e/EI\%20Assets/Reprints...EI\%20P roper/EI1990520

Emotional\%20Intelligence. Pdf.

Suherman dan Budiman, Nandang.

Pendidikan dalam Perspektif

Bimbingan dan

Konseling. Bandung: Upi Press.

Surya, Mohamad (2016); Kecerdasan

Emosional; Garut; Pasca Sarjana STKIP Garut

Taniredja, Tukiran; Irma Pujiati; dan Nyata. 2012. Penelitian Tindakan Kelas

untuk Pengembangan Profesi

Guru ; Praktik, Praktis dan

Mudah. Bandung: Alfabeta.

Yusuf, Syamsu. 2014. Psikologi

Perkembangan Anak dan Remaja.

Bandung:

Remaja Rosdakarya. 